\title{
What Can Stories on History of Science Give to Students? Thoughts of Science Teachers Candidates
}

\section{Canan Laçin-Şimşek}

Assoc. Prof, Sakarya University, Turkey, csimsek@sakarya.edu.tr

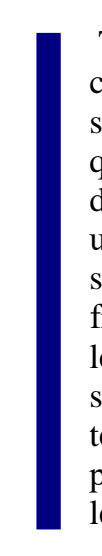

The aim of this study is to determine history of science related stories known by candidate science teachers and their opinions about educational values of those stories. The research is a descriptive study. Data was collected by open ended questions. In the study, 63 teacher candidates from 3th grade which were in the department of science education in $\mathrm{X}$ university took part. Content analysis was used. It was seen that the candidate teachers' stories related to the history of science consisted of the main examples and the stories that were told most frequently were "Newton's apple" and "Archimedes' bath story". Although the level of knowledge about the stories related to the history of science was not sufficient, their awareness of educational value of stories were adequate. Candidate teachers indicated that they would use stories for encouragement, to tell scientific process and scientists' live as well as to take attention and to provide motivation at lessons.

Keywords: history of science, story, candidate teacher, teacher sufficiency, science education

\section{INTRODUCTION}

Stories are narrations we often come across during our daily lives which sometimes entertain us or give a lesson. Thanks to the stories, it is possible to present any opinion or to give any message more quickly and effectively. Stories are also a traditional means of communication that play a role in transferring values belonging to a culture from one generation to another.

Stories are among the educational instruments teachers frequently use in classes in order to help students concentrate, motivate and direct them to the subject matter and make them realize the matters that require attention (Hadzigeorgiou, 2006; Klassen, 2010; Kubli, 1999). The subjects that processed through stories become more understandable and last longer (Kubli, 1999; Metz, Klassen, McMillan, Clough \& Olson, 2007; Norris, Guilbert, Smith, Shahram \& Phillips, 2005; Hadzigeorgiou, 2006). It is also stated that

Citation: Laçin-Simșek, C. (2019). What Can Stories on History of Science Give to Students? Thoughts of Science Teachers Candidates. International Journal of Instruction, 12(1), 99-112. https://doi.org/10.29333/iji.2019.1217a 
stories reduce the communication distance between teachers and students (Metz, etc, 2007).

Stories frequently referred to in teaching of social issues (Şimsek, 2000; Şimşek, 2006) have been neglected for a very long time in science teaching (Begoray \& Stinner, 2005; Fensham, 2001). However, over the past few years, its importance has been noticed and it has become one of the issues highlighted in science teaching (Norris, etc, 2005). Educational values of the stories have begun to be noticed in science education researches in our country yet. Therefore, number of studies related to stories is limited. An experimental study on effectiveness of the stories was conducted by Ayvacı \& Şenel Coruhlu (2009). In the study, effect of explanatory stories on eliminating misconceptions of $6^{\text {th }}$ grade students regarding chemical and physical changes was investigated. As a result of the research, it has been concluded that explanatory stories are effective in eliminating misconceptions regarding physical and chemical changes. Demircioğlu, Demircioğlu \& Ayas (2006) conducted a theoretical study about value of stories in chemistry teaching and exemplary stories were presented. Erten, Kiray \& SenGumus (2013) studied to determine whether a lesson, in which context-based learning approach and scientific stories were used, eliminated students' (aged 11-12) stereotypical images of science and scientists or not. At the end of the study, changes were observed in various categories of stereotypical images of scientists and students' understanding of nature of science.

It is believed that use of stories may have benefits from several aspects. With use of stories in science teaching, it is thought that it is possible to overcome the misconceptions of students as to the fact that science is a mass of facts and rules (Campell, 1998) and it has not connection with their daily lives (Hadzigeorgiou, 2006). Another benefit that may be derived from use of stories in science classes is the chance of concretization owing to stories in science lessons which covers most frequently abstract subjects. Egan (1986) also supports that stories are a very effective in concretization of abstract concepts. Owing to the stories, the student would have an opportunity to realize the point she/he is having a hard time in understanding and have the chance of seeing relation between concept and the daily life. Stories are also effective instruments in building a bridge between old knowledge and new knowledge (Kreps Frisch \& Saunders, 2008). Moreover, stories would make science lessons which are somewhat less popular among students (Kreps Frisch \& Saunders, 2008; Kubli, 1999) more entertaining and interesting. The study conducted by Kreps Frisch \& Saunders (2008) supports these allegations as revealing the result that although students stated that they did not remember details of the stories told, the fact that half of the students stated that stories helped them remember concepts and pointed out that they were more interested in the lessons during narration of stories.

As, in recent years, importance of history of science and nature of science appreciation in science teaching has been realized, use of stories involving historical narrations has become more popular (Klassen, 2009). With the studies conducted about nature of the science, it has been found out that students have several misconceptions (Abd-ElKhalick \& Norman, 2000; Dogan Bora, 2005; Lin \& Chen, 2002) and it has become 
necessary to use various techniques in order to remove these misconceptions. Therefore, it is believed that historical stories would act as an important means in teaching of science nature (Clary \& Wandersee, 1985; Tasar, 2006; Tao, 2002). Through the stories concerning science history which are used correctly, students would have the chance to realize errors in their own thoughts and see the missing parts (Metz, Klassen, McMillan, Clough \& Olson, 2007; Wandersee, 1985). They would be able to realize the historical development phases of the subject/matter they are learning (Roach \& Wandersee, 1995). Fensham (2001) believes that stories are important instruments that help students realize that new scientific knowledge is a result of human endeavor, some of which are shortterm, but most of them are long-term work and that make students aware of the disappointments, pauses, and successes in the endeavoring process.

Thus, using stories in science teaching would humanize science (Hadzigeorgiou, 2006; Stinner, 1995) and it would be clear that it is not a body of facts but also is process. Also, thanks to stories concerning science history, students would have the opportunity of seeing concrete examples as to characteristics of scientists, how their social, cultural and economic conditions affected their works, and how scientific researchers are conducted. Studies conducted about stories confirm these claims. In his study where effect of stories in helping students understand some aspects of nature of science, Tao (2003) has determined that most of the inappropriate thoughts of students about nature of science have turned into appropriate thoughts. At the interviews conducted after two months from the study, it was seen that most of the students were able to remember details included in the stories. Students stated that they liked science stories and they were able to better learn thanks to the stories.

In line with the discussions and researches conducted, it is seen that stories are effective instruments that could be used in science teaching. Therefore, stories should be included in science classes with an appropriate planning where possible. In particular, the history of science should be included in the understanding of what science is and how it has evolved. However, in order for the stories to be effective instruments, science teachers have to possess adequate knowledge on stories concerning science history and realize the educational value of the stories.

It has been determined that there is no study found in the related literature about the benefits of using the stories related to the history of science both in Turkey and abroad and awareness of teachers about these benefits. Therefore, it could be claimed that it is important to determine views of science teacher candidates about using stories of history of science.

\section{Objective of study}

The aim of this study is to determine those stories on science history science teacher candidates are familiar with and their thoughts on educational value of such stories. For this purpose, the answers to the following questions have been sought:

1. Which stories about history of science are science teacher candidates' familiar with? 
2. What are the purposes of science teacher candidates' using stories in science lessons?

\section{METHOD}

This study is a descriptive study to determine the situation. Descriptive studies seek to describe a situation that exists in the past or now and investigate the current situation of a subject (Fraenkel \& Wallen, 2006). During the study, data were collected via openended questions. Open-ended questions were preferred since participants were expected to answer freely. Advantage of these sorts of questions is that researcher is able to receive those answers which are not expected or planned, thereby, having wider and more comprehensive information on the topic (Büyüköztürk, Kılıç Çakmak, Akgün, Karadeniz, \& Demirel, 2008).

\section{Study Group}

Study group of this research is composed of the $3^{\text {rd }}$ grade students from University of $\mathrm{X}$, Department of Science Teaching. Study group is composed of 63 students, including 50 female and 13 male students.

\section{Data collection tools}

In order to collect data of the study, a scale composed of 2 open-ended questions was used. The questions on the form were presented to the expert for determining the purpose of the research. One of these specialists is from science education and the other is from history education and they both give nature and history of science lesson. After their confirmation, the tool was prepared. The prepared form was applied to two students. Students were asked to evaluate the questions in terms of understandability and readability. After the positive answers of the students, the scale was applied to the study group.

Questions included in the scale are as follows:

1. Do you know any stories on history of science which you might use during science classes? Please tell if you do (you can tell more than one story).

2. For what purposes do you use the stories at your classes?

\section{Data analysis}

Data collected was evaluated through content analysis. Basic objective of content analysis is reaching concepts and correlations that may explain the data collected. With this purpose, the collected data are first conceptualized, then, according to the emerging concepts, they are organized in a logical way and the themes describing the data are determined (Yıldırım \& Şimşek, 2003). For the purpose of analysis of data, two researchers took place. First, replies given by each question were examined and coded by the researchers individually. Then the themes were created according to these codes. Number of agreements and disagreements was determined and inter-rater reliability was calculated by using the formula described in Miles and Huberman (1994). It's found as $91 \%$. 
The findings were presented without comment. Teacher candidates' expressions were directly quoted. In order for the data to be more comprehensible, it was preferred to express them in the form of tables.

\section{FINDINGS}

Date collected via open-ended questions during this study was submitted in the form of table.

Problem 1. Answers given by science teacher candidates to the question about stories on history of science they might use at the science classes.

When answers given to this question were examined, it was seen that there were 61 valid answers. It was found that name of scientist was not mentioned in some of the stories or the name was wrong, and such answers were not evaluated. These answers include those students telling about the story or just mentioning the name of the story. Therefore, Table 1 was formed in a way that showed both cases. Since teacher candidates could write more than one story, repetition frequency of the stories was more than the number of teacher candidates who participated in the research. Examples from stories of the students were given in the below table. Codes were used for the science teacher candidates while indicating the examples in the table. Gender and row number of science teacher candidates were used for this purpose. For instance, if one was female and her row number is 24 , it was coded as K24.

Table 1

Stories of science teacher candidates plan to use in their classes

\begin{tabular}{llll}
\multicolumn{2}{l}{ Stories of science teacher candidates } & plan to use in their classes & \\
\hline Strory & Told & Mentioned & Total \\
Newton-gravity & 19 & 2 & 21 \\
Archimedes-water lifting force & 19 & 2 & 21 \\
Einstein- relativity & 9 & 3 & 12 \\
Lavoiser-conservation of mass & 7 & & 7 \\
L. Meitner-fission & 6 & & 6 \\
Edison-light bulb & 4 & & 4 \\
Lavoiser-nutrition & 2 & 1 & 3 \\
Galileo-shape of the earth* & 3 & & 3 \\
G. Bell-telephone & 2 & & 2 \\
Rutherford-atom & 1 & & 1 \\
Faraday-magnetism & 1 & & 1 \\
Pery and friends-radyoactivity & 1 & & 1 \\
Ibn-i Sina (Avicenna)-treatment & 1 & & 1 \\
Egypt-making a calendar & 1 & & 1 \\
\hline
\end{tabular}

* Three stories about Galileo were built on incorrect information. In Galileo's time, the roundness of the world was known, and he was in an effort to prove that the world was turning. Also some students had a misconception that Galileo was executed.

As shown in Table I, most of the stories science teachers candidates expressed in connection with science history were the ones concerning Newton (21) and Archimedes (21), and they were followed by the stories about relativity of Einstein (12). It was seen 
that science teacher candidates had mentioned about 14 different stories. Examples from stories of the students were given below.

Science teacher candidate with code K2 told a story about "Newton": "Once upon a time, Newton went out to a walk. He sat under a tree to have a rest. An apple falls suddenly into his head. He was astonished by fall of the apple. He believes that a force caused fall of the apple. Newton finds out that gravity caused drop of the apple. Not only the apple, it is because of the gravity we are walking on the ground".

Science teacher candidate with code K18 told a story about "Lise Meitner ": "there are many stories about development of science. One of these stories is a story about Lise Meitner who discovered atomic fusion. She was conducting experiments on chemistry with her colleagues at a scientific institution. However, since she was Jewish, she was expelled from the country she lived in and her working environment. She went to stay with her sister. But, her colleague carried on the studies and informed Lise Meitner about the progress made and problems encountered by mail. She came up with some solutions and sent these solutions to her friend by a letter. One day, she wrote that his colleague, during the studies, mass of atom increased, that was impossible, she conducted the experiments with extreme care, yet she could not prevent atom from turning into another atom. Lise Meitner thought about this matter, and based on the calculations she made, atom could be fragment unlike the common belief. This study became so popular in the scientific world. However, her colleague adopted such study for their own name and did not mention name of Lise Meitner."

Science teacher candidate with code $7 \mathrm{~K}$ said "Interest in astronomy which is a branch of science has arisen among Egyptians in the following way. Egyptians were mostly interested in agricultural activities, and their soils were fertile. As a land located along the River Nile, they were able to use the water from river and achieve fertility. However, water level in the river Nile was increasing so high due to precipitation during the winters and was causing floods from time to time, damaging the cultivated territories. Then, Egyptians came up with the idea of a calendar and designed one. Such calendar was as follows. They divided the year into months and seasons as 15 July -15 November, flood, 15 November -15 March, winter, 15 March -15 July, summer. They were cultivating the crops according to these months and were able to harvest fertile products. After inventing the calendar, their enthusiasm in examining movement of sky objects increased."

Science teacher candidate with code K24 said that "the Church wanted to sentence Galileo who argued that earth is round to death. Because it was believed that the earth was like a flat tray. Galileo had saved his own life by submitting his apologies to the church and agreed that the earth is flat."

Science teacher candidate with code K1 said that "I am familiar with a story about science history, vaguely though: I had seen a movie called "Great Idea of Einstein". Einstein used his imagination before he suggested his great idea. He envisages abstract events in his mind. All of these events were estimations about movement of a compass his teacher gave him when he was at the primary school. Through the years, he received 
lectures from great philosophers and came up with special relativity theory as a result of his studies. In the same movie, Lavosier discovers law of conservation of mass. He uses variety of substances to bring them into the reaction. Of course, before doing these procedures, he weighs their masses, and re-weighs the products generated after completion of chemical reaction and finds out that total masses of those elements which entered into reaction and products generated after reaction were the same. From this point, he comes up with law of conversation of mass."

Science teacher candidate with code K2 said that "years and years ago, Archimedes went to bathroom for a bath. He filled the bath tub with water. He stepped in the bathtub. Archimedes realizes that water is flooding out of the bathtub. He believes that portion of his body entering the water is a factor in flooding of water. Archimedes yells out "I Eureka! Eureka!". Archimedes discovers that water has an ascending force."

Problem 2. For what purposes do science teacher candidates plan to use stories on history of science during their lessons?

Answers given to this question were coded, and then grouped under certain themes. Findings derived were given in Table 2 and quotations from facts about the findings were given below the table.

Table 2

Science teacher candidates' objective in using stories on history of science at science lessons

\begin{tabular}{lll}
\hline Theme & Objective for using stories on history of science at the lessons & $\begin{array}{l}\text { Frequency } \\
\text { (N=63) }\end{array}$ \\
Effect on & Explaining the topic/ensuring that it is better understood & 21 \\
cognitive & Ensuring that topic remains in the mind of student longer & 8 \\
characteristics & Ensuring that students think /question/generate ideas /imagine & 6 \\
& Showing concrete examples & 5 \\
Effect on & To draw attention /interest & 15 \\
emotional & To motivate & 9 \\
characteristics & To render the lesson interesting / entertaining & 6 \\
& To evoke curiosity & 4 \\
& To develop positive attitude & 3 \\
& To eliminate prejudices of the students & 2 \\
Acting as & To eliminate hesitations of the students & 1 \\
model for the & To explain importance of fight /determination /patience /vigor & 16 \\
students & To demonstrate importance of curiosity /questioning /research & 9 \\
& To encourage students to become scientists & 8 \\
& To show importance of the work & 8 \\
Connected & To encourage students to discover /research & To show characteristics of the scientists \\
with scientists & To show that scientists are normal people & 3 \\
& To show who made the discoveries / inventions & 11 \\
& To show thinking style of the scientists & 5 \\
& To ensure that students get to know the scientists & 3 \\
& To explain the reasons underlying studies of thee scientists & 2 \\
Connected & To demonstrate correlation of science matters with daily life & 8 \\
\hline
\end{tabular}




\begin{tabular}{lll}
\hline with & To explain how information /knowledge has evolved & 7 \\
of the science & To demonstrate hardships of scientific study & 4 \\
& To demonstrate that scientific study is a job of process & 3 \\
& To show that science is based on observation & 3 \\
& To explain what science is & 3 \\
& To demonstrate that science / discoveries are made in line with \\
the requirements & 3 \\
To explain under what conditions science / knowledge develops & 2 \\
To show that scientific advancement is constant & 2 \\
To draw attention to scientific ethics & 2 \\
To exemplify correlation between science and religion & 2 \\
To show how important to look at problem solutions from & 1 \\
different perspectives & \\
To talk about the fact that scientific information may change & 1 \\
To ensure that students understand importance of science & 1 \\
To show that people have been trying to understand the nature & 1 \\
for ages &
\end{tabular}

As seen in the Table II, it is possible to group the expressions of science teacher candidates about objectives for using stories on history of science during the lessons under 5 themes. These themes include contribution to cognitive characteristics of students, contribution to their emotional characteristics, role modeling for the students, characteristics of science and scientists. With regards to theme of contributing to cognitive characteristics of students, the most frequently used expression of science teacher candidates is, "explaining the topic/ensuring that topic is better understood (21)" and "ensuring that topic remains on student's mind longer (8)". With regards to emotional characteristics, they have explained that they aim to "draw attention/interest (15)" and "motivate (9)". Under the theme of role modeling for the students, they used expressions that read as "explaining importance of fight /vigor/determination (16)" and "showing importance of curiosity /questioning/research (9)". Under the theme of scientists, they most frequently mentioned about "explanation of characteristics of scientists (11)". Under the theme of characteristics of science, the most frequently repeated expressions is "showing correlation of scientific matters with daily life (8)", "explaining how science /knowledge developed (7)" .

Expressions regarding science teacher candidates' objectives in using stories on science history at science lessons are as follows. Words were written in italic in order to give an idea about expressions used while creating codes in quotations made.

Science teacher candidate with code K2 who stated that she would use stories about Newton and Archimedes during the lessons said that "I use such story when telling the students about ascending power of water. I encourage students imagine, think. In this way, I make students learn in a permanent way. I show them that they can be scientists. Interest by the student in the lesson goes up. I ensure that lessons are more fun. I use story on Newton when talking about gravity force. When I start the lesson with this story, it is a lot easier to draw attention of students to a particular point. I make sure that they get to know the scientists. Thanks to the story, what they learn remains longer in their minds". The student with code E12 who mentioned about story on Newton and 
Archimedes said, "I tell these stories to draw attention of students and increase their curiosity towards the topics. However, I also tell the students that inventions are not that easy, and they come into being after many studies".

Science teacher candidate with code $\mathrm{K} 3$ who said that she is going to tell story about the Newton during the lessons said that "the greatest objective in telling this story is ensuring that my students understand how science advanced from past to modern day. Thus, they are going to be aware that gravity has not been discovered all of a sudden, and before and after that several scientists have worked on this topic. Most importantly, I would aim to make them understand how and who came up with a theory and phases in development of the theory. I believe that more permanent teaching is possible by doing that. Because these sorts of stories tell the students about the respective topic and constant advancement in science." The candidate with code K19 who mentioned about Newton said, "I would tell about thinking style of Newton, one of the scientists. I would tell there is a big difference between fall of an apple or any object and suspension of moon. Everyone can think of the apple in this story, yet it is the scientists that think of the moon".

Science teacher candidate with code K15 who mentioned about Archimedes story said, "looking back upon the history, the basic knowledge we learned theoretically during the lessons was the result of events that people encountered during their daily lives. Of course, what draws our attention is scientist's curious, questioning character in terms of development of science. I use these stories at the lessons in order to make students better understand characteristics of people who made important discoveries and science has developed as a result of daily lives, requirements, and observations and may further develop. I believe these stories are influencing and permanent."

Science teacher candidate with code E13 who mentioned about two stories about İbn-i Sina (Avicenna) said, "I use this story during the lesson in order to make students understand that they have to conduct their researches apart from what they are told during the lessons. Apart from what teacher tells, students may further improve themselves by researching and learning". The same student said the following about the 2nd story he told, "I would use this story to make students understand that one needs to look from different perspective in order to solve the problems and different ways of solution may be used."

Science teacher candidate with code K18 who mentioned about the story of Lise Meither said, "in this story, experiments were repeated with patience. This shows us that science is not something easy and requires long hours of work and patience. In this way, the idea that one should never give up even if incorrect results have been obtained, and one should continue to work until she/he is sure is instilled on the students. Nothing is what it seems to be in the science world. I will explain that original owners of inventions are sometimes correctly known. I will teach them that there is no place for ambition in science and rights of original owners of the inventions should not be stolen. Also, I can explain how having different beliefs in ancient times affected development of science negatively with this story." 
Science teacher with code K33 who mentioned about the story of Lavosier and L. Meither said, "I will tell this story to demonstrate how hard science is, it is full of hard, bumpy roads, thereby, these inventions were not made so easily, and the science has an important place in our lives. Also these stories bridge the gap between students and the scientists. Students will understand that scientists are just like themselves, and science requires patience and hard work."

The student with code E56 who mentioned about the story on Galileo said, "the reason I will tell this story to students during the class is ensuring that students not only adopt the existing knowledge at the science lessons, spend more time and think on it, and reach a capacity where they can come up radical and striking ideas. Also, I would share this story to explain that what we know may be incorrect, the truth can change, and demonstrate the variable structure of the science."

Although this study does not include evaluation of accuracy level of the stories told by the students, it has been found out that that there are two points which need to be emphasized. One of them is frequent emphasis on coincidences, and the second one is narrations about Galileo. All students mentioning about Galileo have two misconceptions. One of them is the belief that Galileo has discovered that earth is flat, and the second one is that he has been sentenced to death by inquisition court. Prior to Galileo, Magellan proved that the earth is flat. Galileo claimed that the world spins. Also, he was not sentenced to death, after so-called relinquishment from his claim; Galileo was sentenced to home detention. With regards to emphasis on coincidences, looking at the expression of the student with code E32 will be useful in understanding the situation: "as a matter of fact, this story is not the type of story that will encourage the students and increase their interest in the lesson. But, I believe that explanations I will make at the end of the story will destroy prejudices of the students. Newton has discovered one of the most critical topics in the world merely by a coincidence. So, engaging oneself with science, coming up with theories and laws and becoming one of the most important scientists in the world is not that hard ....." Here, emphasis on coincidence is too much. Similar expressions have been encountered in expressions of the other students too. By contrast, message from the stories should not be that scientists discovered something suddenly (Matthews, 1994). However, that is not the truth. Objective of these narrations should not be drawing attention of the students alone. For instance, student should be aware that, in order for Newton to discover law of gravity as a result of an apple dropping on the ground while sitting under a tree, he must have conducted studies, observations, and he had not made a discovery all of a sudden, and he had been working on this matter for a very long time. Student should be able to see that he has benefited from ideas of his predecessors (Laçin-Şimşek, 2009).

\section{DISCUSSION AND CONCLUSION}

Findings derived from open-ended questions show that stories about history of science which science teacher candidates are familiar with are composed of some major examples. Stories are the ones we frequently come across in the school books, media, and popular books. Stories which science teacher candidates have said they would use during the lessons are mostly stories on Archimedes and Newton. Metz et al. (2007) and 
Stinner (1995) also state about similar findings, and they indicated that when students were asked about their experience on science lessons, most of them remembered Eureka! stories. They stated that bathroom legend of Archimedes, apple falling on head of Newton and experiment by Galileo at the Pisa tower were among the examples that could be easily remembered by even the most uninterested students. In this study, examples with Galileo are not as intense as the other examples. Reason for this may be explained as the fact that stories about Galileo have not been offered room in national school books so far. Besides, it has been observed that science teacher candidates talk about Lise Meitner, Perry and their colleagues. These names are beyond the general tendency. It is possible to think that awareness about these scientists is due to Modern Physics science teacher candidates have taken at the $2^{\text {nd }}$ class. In line with the findings derived, it could be claimed that science teacher candidates do not have adequate knowledge and diversity about historical stories.

When science teacher candidates were asked about for what purpose they would use the stories, we have come across a different scene as different answers have been received from the science teacher candidates about educational value of the stories. Answers of the science teacher candidates have been grouped under five different themes. These themes include contribution to cognitive characteristics of students, contribution to their emotional characteristics, role modeling for the students, giving characteristics of science and scientists through the stories. It has been seen that science teacher candidates attributed some duties to the stories such as better understanding of the story, drawing attention, motivation and they also assigned some functions to the stories such as encouragement, showing hardships of science, and explaining that scientists are normal people. Although they do not have adequate level of knowledge about the stories, their awareness about intended use has been considered positive. When rewieving the related literature, it has been revealed that stories increase curiosity of the students, help students understand the topics (Hadzigeorgiou, 2006), give students the opportunity of increasing academic achievement (Şimşek, 2000), assured interest and motivation for them (Kubli, 1999). Moreover, stories about scientists improve the image of students about science and scientists and humanize science, have a significant effect on improving students cognitively (Otluoglu, 2001). In this context, it is possible to say that science teacher candidates have adequate awareness about use of stories in teaching.

Importance and role of stories in science teaching should be laid out in details (Norris, etc., 2005). Positive results have been obtained from studies conducted on the stories. However, it has also been pointed out that stories have to be used correctly in order to obtain desired results in teaching (Metz, Klassen, McMillan, Clough \& Olson, 2007). Therefore, stories concerning science history that are to be used in the lessons should be prepared carefully, and they should be formed through sources that are as reliable as possible. At the class titled "nature and history of science" that is part of Science Teaching Syllabus, stories that might be used in primary school science lessons should be introduced to the students, and information repertoire of science teacher candidates should be enriched. 
This study was conducted with teacher candidates. A similar study could be done with teachers. In this study, only a form consisting of open-ended questions was used as a means of collection and this constitutes the limit of the study. In a similar work to be done, semi-structured interviews are recommended to ensure very diversity.

\section{REFERENCES}

Abd-El-Khalick, F. \& Norman G. L. (2000). The Infuence of History of Science Courses on Students' Views of Nature of Science. Journal of Research in Science Teaching, 37(10),1057-1095.

Ayvacı, H. S. \& Senel Coruhlu, T. (2009). Fiziksel ve Kimyasal Değişim Konularındaki Kavram Yanılgılarıın Düzeltilmesinde Açıklayıcı Hikâye Yönteminin Etkisi. Ondokuz Mayıs Üniversitesi Eğitim Fakültesi Dergisi, 28, 93-104.

Begoray, D. L. \& Stinner, A. (2005). Representing Science Through Historical Drama. Science \& Education, 14, 457-471.

Büyüköztürk, Ş., Kılıç Çakmak, E., Akgün, O. E., Karadeniz, Ş., ve Demirel, F. (2008). Bilimsel Arastırma Yöntemleri. Pegem A Yayınc1lık, Ankara.

Campbell, P. (1998). Using Stories to Enrich the Physics Curriculum. Physics Education, 33, 356-358.

Clary, R. M. \& Wandersee, J. H. (2006). Mary Anning: She's More Than "Seller of sea shells by the Seashore." The American Biology Teacher, 68(3), 153-157.

Demircioglu, H., Demircioglu, G. \& Ayas, A. (2006). Hikayeler ve Kimya Öğretimi. Hacettepe Universitesi Egitim Fakültesi Dergisi, 30, 110-119.

Doğan Bora, N. (2005). Türkiye genelinde ortaoğretim fen branşl ögretmen ve ögrencilerinin bilimin doğası üzerine görüşlerinin araşstırlması. Ph.D. Dissertation Univ. of Gazi, Ankara.

Egan, K. (1986). Teaching as story telling. Ontario: Althouse Press, London.

Erten, S., Kiray, S.A., \& Sen-Gumus, B. (2013). Influence of Scientific Stories on Students Ideas about Science and Scientists. International Journal of Education in Mathematics, Science and Technology, 1(2), 122-137.

Fensham, P. (2001). Science as Story: Science Education by Story. Asia-Pacific Forum on Science Learning and Teaching, 2 (I).

Fraenkel, J.R., \& Wallen, N.E. (2006). How to design and evaluate research in education. McGraw-Hill, .New York.

Hadzigeorgiou, Y. (2006). Humanizing the Teaching of Physics Through Storytelling: The Sase of Current Electricity. Physics Education, 41, 41-46.

Klassen, S. (2009). The Construction and Analysis of a Science Story: A Proposed Methodology. Science \& Education, 8, 401-423. 
Klassen, S. (2010). The Relation of Story Structure to a Model of Conceptual Change in Science Learning. Science \& Education, 19, 305-317.

Kreps Frisch, J. \& Saunders, G. (2008). Using Stories in an Introductory College Biology Course. Journal of Biological Education, 42 (4), 164-169.

Kubli, F. (1999). Historical Aspects in Physics Teaching: Using Galileo's Work in a New Swiss Project. Science \& Education, 8, 137-150.

Laçin-Şimşek, C. (2009). Fen ve Teknoloji Dersi Öğretim Programları ve Ders Kitapları Bilim Tarihinden Ne Kadar ve Nasıl Yararlanıyor?. Ilkogretim Online, 8 (1), 129-145.

Lin, H. \& Chen, C.-C. (2002). Promoting Preservice Chemistry Teachers' Understanding about the Nature of Science through History. Journal of Research in Science Teaching, 39(9), 773-792.

Matthews, M. R. (1994). Science Teaching: The Role of History and Philosophy of Science. Routledge, New York.

Metz, D., Klassen S., McMillan, B., Clough, M. \& Olson, J. (2007). Building a Foundation for the Use of Historical Narratives. Science \& Education, 16, 313-334.

Miles, M, B., \& Huberman, A. M. (1994). Qualitative data analysis: Anexpanded Sourcebook. (2nd ed). Thousand Oaks, CA: Sage.

Norris, S., Guilbert, M., Smith, M., Shahram, H., \& Phillips, L. (2005). A Theoretical Framework for Narrative Explanation in Science. Science Education, 89(4), 535-554.

Otluoglu, R. (2001). İlkogretim okulu 5. sinif sosyal bilgiler ogretimimde yazılı edebiyat ürünlerini ders aracı olarak kullanmanın duyussal davranıs özelliklerini kazandırmaya etkisi., Master Dissertation Univ. of Marmara, İstanbul.

Roach, L. E. \& Wandersee, J. H. (1995). Putting People Back into Science: Using Historical Vignettes. School Science \& Mathematics, 95(7), 365-370.

Şimşek, A. (2006). İlkogretim Sosyal Bilgiler Dersinde Tarihsel Hikayeye Yönelik Öğrenci Görüşleri. GÜ, Gazi Eğitim Fakültesi Dergisi, 26 (1), 187-202.

Şimşek, A. (2000). İlköğretim sosyal bilgiler öğretiminde hikaye anlatım yönteminin (storytelling) kullanımı. Master dissertation of Unv. of Gazi, Ankara.

Stinner, A. (1995). Contextual Settings, Science Stories and Large Context Problems: Toward a More Humanistic Science Education. Science Education, 79(5), 555-81.

Tao, P. K. (2002). A Study of Students' Focal Awareness When Studying Science Stories Designed for Fostering Understanding of the Nature of Science. Research in Science Education, 32, 97-120.

Tao, P. K. (2003). Eliciting and Developing Junior Secondary Students' Understanding of the Nature of Science through a Peer Collaboration Instruction in Science Stories. International Journal of Science Education, 25(2), 147-171. 
Tasar, M. F. (2006). Probing Preservice Teachers' Understandings of Scientific Knowledge by Using a Vignette in Conjunction with a Paper and Pencil Test. Eurasia Journal of Mathematics, Science and Technology Education, 2(1).

Wandersee, J. H. (1985). Can the History of Science Help Science Educators Anticipate Students' Misconceptions?. Journal of Research in Science Teaching, 23(7): 581-597.

Yıldırım, A. \& Şimşek, H. (2003). Sosyal Bilimlerde Nitel Arastırma Yöntemleri. Seçkin Yayınları, Ankara. 